\title{
Molecular determinants analysis and co receptor tropism prediction of V3 loop of HIV-1 "C" clade sequences isolated from India using insilico approach
}

\author{
H Jemmy Christy ${ }^{*}$, D Alex Anand, Renuka Pasupuleti
}

From First International Science Symposium on HIV and Infectious Diseases (HIV SCIENCE 2012)

Chennai, India. 20-22 January 2012

\section{Background}

The V3 loop of the env gene in HIV-C type is considered as a major viral determinant for coreceptor specificity. The tip motif of v3 loop is known for antibody neutralization, so sequence variation in this motif have an impact on virus infectivity and disease progression. So analysis of genetic diversity in the V3 loop Tip motif help us to improve the CCR5 antagonist's development as well as vaccine target.

\section{Methods}

HIV-1 "C" type env sequences of Indian isolates were retrieved from HIV sequence database. Coreceptor Tropism prediction by different web-based interpretation system like (WebPSSM, Geno2pheno, (ds) Kernel, WetCat) was performed. The diversity of V3 loop tip motif, glycosylation motifs were analyzed using N-Glycosite. Relative frequencies of each amino acid in v3 loop were determined using Web Logo.

\section{Results}

In this study, lower numbers of positive charges of v3 loop, in the range of 4 to 5 , reveals the prevalence of R5 tropism. Thus majority of the V3 sequences of HIV-1 Indian isolates were predicted as R5-tropism and we identified few mutational prevalence like for R5-predicted viruses -E25D, Y21F and for X4-predicted viruses E25KRQ, I12, H34Y. Overall eight different tetrameric tip motifs [GPGQ, GPGR, GPAQ, GPRR, GPGL, RPRQ, EPGQ, and GSGQ] were identified.

* Correspondence: jemmyjacob@gmail.com

Sathyabama University, Chennai, India

(C) 2012 Christy et al; licensee BioMed Central Ltd. This is an Open Access article distributed under the terms of the Creative Commons Attribution License (http://creativecommons.org/licenses/by/2.0), which permits unrestricted use, distribution, and reproduction in any medium, provided the original work is properly cited.

\section{Conclusion}

High prevalence of R5 tropism, higher no of conserved motif regions in the V3 sequence among HIV strains in India reveals the need of potential CCR5 antagonists. sequences and this pattern could be an ideal target for AIDS therapy.

Published: 4 May 2012

doi:10.1186/1471-2334-12-S1-018

Cite this article as: Christy et al:: Molecular determinants analysis and co receptor tropism prediction of V3 loop of HIV-1 " $\mathrm{C}$ " clade sequences isolated from India using insilico approach. BMC Infectious Diseases 2012 12(Suppl 1):018. GPGQ and GPGR is highly conserved in all the
Submit your next manuscript to BioMed Central and take full advantage of:

- Convenient online submission

- Thorough peer review

- No space constraints or color figure charges

- Immediate publication on acceptance

- Inclusion in PubMed, CAS, Scopus and Google Scholar

- Research which is freely available for redistribution

Submit your manuscript at www.biomedcentral.com/submit
Biomed Central 